\title{
Microbial regeneration of ammonium in the water column of Davies Reef, Australia*
}

\author{
Charles S. Hopkinson, Jr$^{1}$, Barry F. Sherr ${ }^{1}$, Hugh W. Ducklow ${ }^{2}$ \\ ' University of Georgia, Marine Institute, Sapelo Island, Georgia 31327, USA \\ ${ }^{2}$ University of Maryland, Horn Point Environmental Laboratory, Cambridge, Maryland 21613, USA
}

\begin{abstract}
Ammonium regeneration by microheterotrophs was measured during winter in the water column of Davies Reef, on the Great Barrier Reef. Regeneration rates were among the lowest reported,

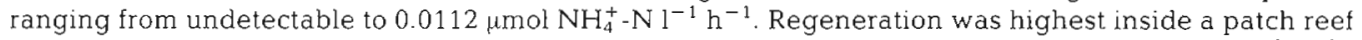
(0.0112), followed by reef flat (0.0050), lagoon (0.0017) and fore-reef $\left(0.0013 \mu \mathrm{mol} \mathrm{NH}_{4}^{+}-\mathrm{N} \mathrm{l}^{-1} \mathrm{~h}^{-1}\right)$. Bacteria and heterotrophic nanoplankton accounted for 40 to $88 \%$ of the $\mathrm{NH}_{4}^{+}$regenerated in $208 \mu \mathrm{m}$ filtered water. There was a trend of increasing importance of these organisms as water passed from the fore-reef, across the reef flat, and into the lagoon and patch reef areas. Remineralization was highest where water was in most intimate contact with the reef benthos, which may reflect a response of the pelagic community to the input of organic matter (e.g. mucus) to the water column by the reef benthos. A first approximation of the relative importance of bacteria versus heterotrophic nanoplankton in $\mathrm{NH}_{4}^{+}$ regeneration, established from measures of biomass and growth rates for both groups, suggested that suspended bacteria were about an order of magnitude more important than nanoplankton. Pelagic ammonium regeneration supplied almost 3 times more inorganic $\mathrm{N}$ to the water column in lagoonal portions of the reef than sediment nutrient regeneration did. Only over the reef flat was pelagic $\mathrm{NH}_{4}^{+}$ regeneration sufficient to fully meet calculated phytoplankton $\mathrm{N}$ demands. Long biologically-mediated turnover times of $\mathrm{NH}_{4}^{+}$(21 to $154 \mathrm{~h}$ ) suggest a greater importance of physical rather than biological processes in the water column of this reef during winter.
\end{abstract}

\section{INTRODUCTION}

Nutrient requirements of neritic primary producers are met through a combination of inputs from freshwater runoff, coastal upwelling, deep water intrusions and local pelagic or benthic nutrient regeneration. Coral reefs away from continental margins generally exist in oligotrophic, nutrient-poor regions and the input of inorganic nutrients from the surrounding milieu is frequently accepted as being relatively unimportant (Johannes et al. 1972). With respect to ammonium - the preferred and frequently most limiting nutrient species to the gross primary production of phytoplankton (Ryther \& Dunstan 1971, McCarthy et al. 1977) - the relative importance of sediment and pelagic regeneration has not been determined. In coral

\footnotetext{
- Joint contribution from the University of Georgia Marine Institute (No. 590), the University of Maryland Horn Point Environmental Laboratory, and the Microbial Ecology on a Coral Reef Workshop (MECOR No. 14)
}

reefs (Kinsey 1985a, Ducklow 1987) and shallow water systems in general (Hargrave 1973), most metabolism is mediated by the benthos and it might be expected that ammonium regeneration in the sediments largely dictates nutrient concentrations in the overlying water column. However, as water approaches, passes over reef crest and reef flat regions, and exits from the back reef, microbial activity in the water column appears to be greatly stimulated in response to utilizable substrates released from the reef community (Johannes 1967, Ducklow 1987). The living and detrital organic nitrogen released by the reef community is remineralized to ammonium and $\mathrm{CO}_{2}$ via microzooplankton catabolism and excretion, and by the metabolic processes of the pelagic, heterotrophic microbial community (Dugdale \& Goering 1967, Harrison 1980).

In this paper, we present the first direct estimates of ammonium regeneration by microheterotrophs in the water column at Davies Reef, on the Great Barrier Reef. Also reported are estimates of the relative importance 
of benthic versus pelagic ammonium regeneration, production rates of pelagic bacteria and heterotrophic nanoplankton, the relative importance of bacteria versus heterotrophic nanoplankton and microplankton in regenerating inorganic nitrogen, and the spatial variability in pelagic ammonium regeneration in a coral reef system.

\section{DESCRIPTION OF THE AREA}

Davies Reef, a platform reef of about 5.8 by $2.6 \mathrm{~km}$ $\left(18^{\circ} 51^{\prime} \mathrm{S} ; 147^{\circ} 39^{\prime} \mathrm{E}\right)$, is on the inner edge of the main reef tract on the eastern half of the continental shelf off Townsville, Australia (Fig. 1). The reef is partially surrounded by other coral reefs separated by water in excess of $60 \mathrm{~m}$ depth. The windward face of the reef comprises a solid wall with extensive cover of corals plus other invertebrates and algae, especially Halimeda spp. Behind the fore-reef slope is a reef flat of mixed substratum and increasing live coral cover to leeward. A distinct algal ridge or rubble bank is absent from this reef. The leeward side is a broken wall with channels and actively growing areas. The lagoonal system is generally 10 to $25 \mathrm{~m}$ deep with isolated patch reefs (bommies) which increase in size at the back of the reef (northwest face). During August 1984, water temperature averaged 22 to $24^{\circ} \mathrm{C}$, salinity $35.3 \mathrm{ppt}$, tidal range 1 to $3.5 \mathrm{~m}$ (neap/spring), and day length $11.5 \mathrm{~h}$. Winds were generally light and variable but there were periods when they exceeded $10 \mathrm{~m} \mathrm{~s}^{-1}$. During sampling, winds ranged from near calm to $3 \mathrm{~m} \mathrm{~s}^{-1}$. Water residence time ranged from less than $30 \mathrm{~min}$ on the reef flat, up to about 12 to $48 \mathrm{~h}$ in the East lagoon (Kinsey 1985b, Pickard 1986, MECOR unpubl. data Australian Institute of Marine Sciences, Townsville, Queensland).

\section{MATERIALS AND METHODS}

Pelagic ammonium remineralization was investigated during August 1984 at 4 locations along a transect extending from the seaward side of the fore-reef to the rear of Davies Reef and running mostly parallel to the direction of net water flow (Fig. 1). As one of our sampling objectives was to determine whether significant differences in growth rate and remineralization by the heterotrophic microbial community in the water column could be detected as water flowed over various benthic subsystems of the coral reef, we chose sites extending across the entire reef system. Site 1 was a fore-reef site in $57 \mathrm{~m}$ of water approximately $100 \mathrm{~m}$ in front of the reef crest. Site 2 was at the downstream edge of an approximately $300 \mathrm{~m}$ wide reef flat region

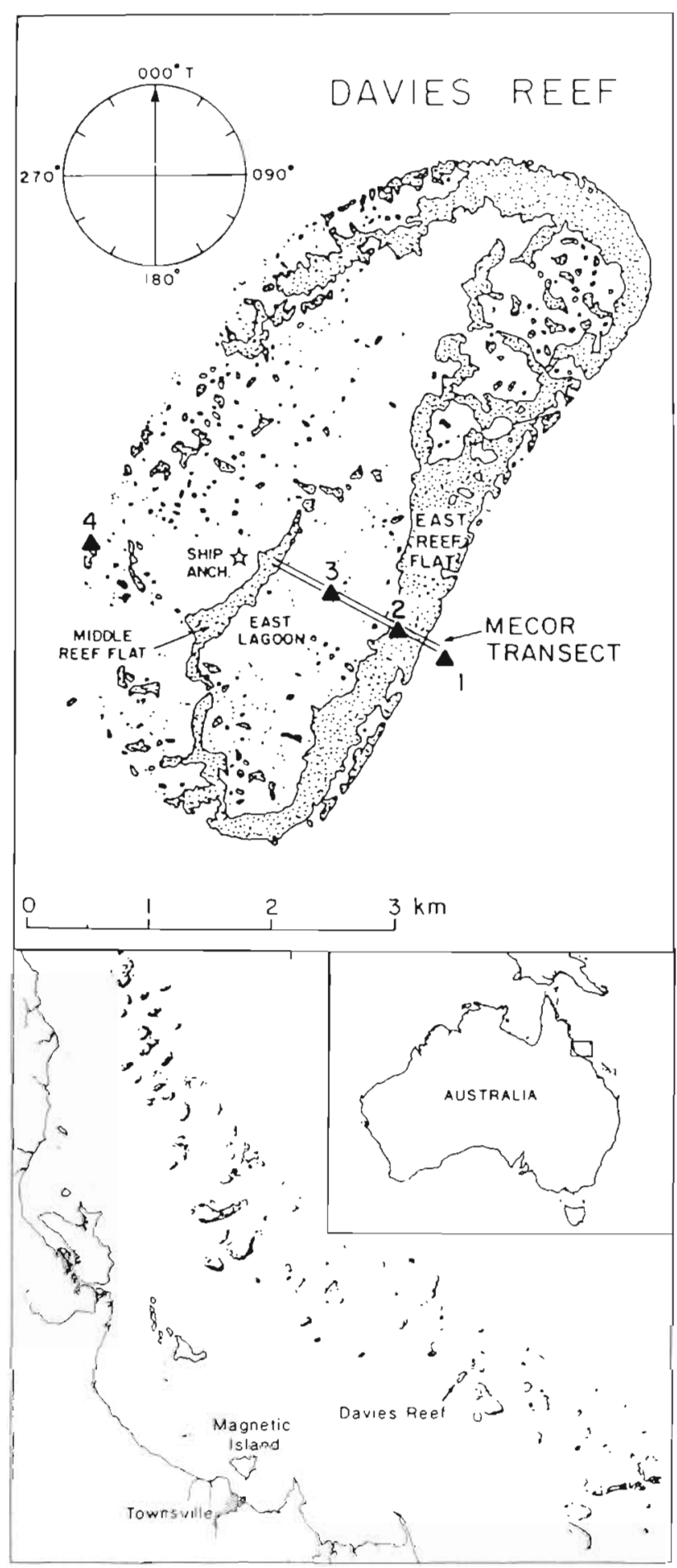

Fig. 1. Location of sampling sites at Davies Reef, central Great Barrier Reef, off Townsville, Australia

(exposed only during very low tides). Site 3 was in $15 \mathrm{~m}$ of water in the center of the East (front) lagoon at Davies. Site 4 was internal to a large (approximately 60 by $30 \mathrm{~m}$ ) cavernous patch reef at the rear of the reef. Rhodamine dye injections indicated that the cave sam- 
pled (approximately $1 \mathrm{~m}$ internal diameter by $15 \mathrm{~m}$ long) had sluggish unidirectional flow down from the top of the patch reef flat and out of the rearward face of the patch reef. At Sites 1,2 and 3, water was collected with 5 or $10 \mathrm{l}$ Niskin bottles at mid water column depth. From near center of the patch reef cave, water was collected with a peristaltic pump through $2 \mathrm{~mm} \mathrm{ID}$ Tygon brand vinyl tubing (Fisher Scientific, Springfield, New Jersey, USA) attached to a bamboo spar in a manner similar to that of Andrews \& Muller (1983). All sample incubations were performed aboard a research vessel anchored in the lagoon.

For each water mass sampled, ammonium regeneration assays were run using $208 \mu \mathrm{m}$ and $15 \mu \mathrm{m}$ screened water. Size fractionation was accomplished by reversefiltration. Within $30 \mathrm{~min}$ of collection, water for ammonium regeneration experiments was gently transferred through $208 \mu \mathrm{m}$ screening to a $12 \mathrm{l}$ polypropylene bucket. While bucket contents were slowly stirred, $2.4 \mathrm{l}$ portions were siphoned into two $2.5 \mathrm{l}$ glass reagent bottles. A PVC tube $(20 \mathrm{~cm}$ ID) with $15 \mu \mathrm{m}$ nitex screening (DuPont woven nylon monofilament Tetko Inc., Elmsford, New York, USA) attached across the bottom was allowed to sink under its own weight $(<2.5 \mathrm{~cm}$ head) into the water remaining in the bucket. Reverse-filtered water was gently siphoned from inside the tube into two $2.5 \mathrm{l}$ glass bottles.

Sufficient $\mathrm{N}^{15}-\left(\mathrm{NH}_{4}\right)_{2} \mathrm{SO}_{4}(99 \%)$ was added to each bottle to make a final concentration of $0.1 \mu \mathrm{M}{ }^{15} \mathrm{~N}$. Immediately after tracer addition, each bottle was swirled and an $800 \mathrm{ml}$ sample withdrawn. The bottles were then placed in an on-deck flowing seawater incubator covered with neutral density screening allowing $50 \%$ light transmission. From the $800 \mathrm{ml}$ samples, $300 \mathrm{ml}$ were used to rinse filtering apparatus (including Gelman glass fiber GF/F) and polyethylene storage bottles and then discarded. Another $100 \mathrm{ml}$ were used for zero-time ammonium analysis and the remainder of the filtrate was frozen until further processing on shore. Bottles were resampled 1 and $3 \mathrm{~h}$ after tracer addition.

Ammonium concentration was redetermined following thawing and ammonium stripped from stored samples within $5 \mathrm{~d}$ of collection at the onshore laboratory. Prior to stripping, $1.5 \mu \mathrm{mol}{ }^{14} \mathrm{~N}-\left(\mathrm{NH}_{4}\right)_{2} \mathrm{SO}_{4}$ carrier were added to the $400 \mathrm{ml}$ sample. The solvent extraction procedure described by Dudek et al. (1986) was used to strip ammonium nitrogen for the determination of relative ${ }^{15} \mathrm{~N}$ abundance. In this procedure ammonium is converted to indophenol using a modification of the phenol-hypochlorite reaction for seawater ammonium analysis. Sodium aquopentacyanoferrate is used rather than sodium nitroprusside for catalyzing the reaction. The indophenol is extracted into methylene chloride, concentrated by partial evaporation of the solvent and dried on a glass fiber filter (Whatman $934 \mathrm{AH}$ ). Particular care was taken to ensure that sample $\mathrm{pH}$ was lowered to the optimum level $(\sim \mathrm{pH}$ $6.0)$, and that vacuum pressure $(700 \mathrm{~mm} \mathrm{Hg})$ and water bath temperature $\left(35^{\circ} \mathrm{C}\right)$ were precisely controlled during concentration. Filters were dried at $80^{\circ} \mathrm{C}$ and stored in plastic scintiliation vials. Upon return to the USA, vials with filters were stored under vacuum until ${ }^{15} \mathrm{~N}$ analysis.

${ }^{15} \mathrm{~N}$ content was analyzed by emission spectrometry following a modification of the micro-Dumas procedure (Dudek et al. 1986). Filters were ground with $0.5 \mathrm{~g}$ precombusted $\left(500^{\circ} \mathrm{C}\right)$ cupric oxide wire (Fisher Scientific, Springfield, New Jersey, USA) and stored in evacuated vacutainers (vacuum-tight test tubes - Becton-Dickinson, Rutherford, New Jersey, USA) until placement into a $5 \mathrm{~mm}$ OD pyrex glass discharge tube containing about $2 \mathrm{~cm}$ precombusted $\left(900^{\circ} \mathrm{C}\right) \mathrm{CaO}$. The tubes were evacuated to $<10^{-5}$ Torr $\left(=1.3 \times 10^{-3}\right.$ Pa), sealed, combusted for $8 \mathrm{~h}$ at $500^{\circ} \mathrm{C}$ and analyzed on a Jasco emission spectrometer.

A modified Strickland \& Parsons (1972) procedure was employed for determining ammonium concentration. Sodium nitroprusside was recrystallized prior to reagent preparation in order to lower blank values. Absorbances were read at $630 \mathrm{~nm}$ in $10 \mathrm{~cm}$ path-length cells. All glassware used in these analyses was well aged, combusted at $450^{\circ} \mathrm{C}$, soaked in $10 \% \mathrm{HCl}$ for at least $4 \mathrm{~h}$ and rinsed thoroughly with deionized water before use. Incubation bottles were rinsed further with the appropriately size-fractionated seawater. Sample bottles and separatory funnels were further cleansed of ammonium by adding reagents immediately prior to use (burnt out).

Ammonium regeneration rates were calculated from measurements of ammonium concentration and isotope ratio according to the Blackburn (1979) equations (Laws 1984). Corrections to the measured isotope ratio were made for isotope contamination during sample freezing, ammonium extraction, and micro-Dumas combustion.

Estimates of bacterial and microflagellate biomass and production were made as described in Ducklow \& Hill $(1985 a, b)$ and Sherr et al. $(1984,1986)$.

\section{RESULTS AND DISCUSSION}

During the sampling period, ammonium standing stock concentrations ranged from 0.07 to $0.37 \mu \mathrm{M}$ throughout the water column at Davies Reef (Table 1). Although sample variability over depth at any one site was very low (average coefficient of variation $0.03 \mu \mathrm{M}$ ), temporal and horizontal spatial variability were significant (coefficient of variation $0.47 \mu \mathrm{M}$ ). There were no 
Table 1. Concentrations of ammonium in the water column at several sites within Davies Reef. All samples were collected in August 1984. Units are $\mu M$; values in parentheses are standard deviations

\begin{tabular}{|lccc|}
\hline Location & $\begin{array}{c}\text { Mean } \\
\text { concentration }\end{array}$ & $\begin{array}{c}\text { No. of } \\
\text { samples }\end{array}$ & Range \\
\hline Fore-reef & $0.201(.05)$ & 6 & $0.12-0.25$ \\
Reef flat & $0.174(.06)$ & 6 & $0.10-0.27$ \\
Lagoon & $0.185(.11)$ & 14 & $0.07-0.37$ \\
$\begin{array}{l}\text { Patch reef } \\
\text { Internal }\end{array}$ & 0.24 & 2 & $0.21-0.27$ \\
External & 0.14 & 2 & $0.13-0.14$ \\
\hline
\end{tabular}

clear cut diel or horizontal trends apparent in the distribution of ammonium with the exception of the patch reef, where concentrations were higher inside the patch reef structure than they were in the surrounding water. Andrews \& Muller (1983) noted a similar pattern for nitrate in patch reefs at Davies Reef. The absence of spatial patterns within the overall system indicates no discernible effect on ammonium concentrations due to passage of water over the reef benthos. This is in contrast with the frequent observation of net export of $\mathrm{NO}_{3}^{-}$from coral reefs (Webb et al. 1975, Andrews \& Muller 1983). The distribution of ammonium is also in contrast with the pattern Kinsey observed (1985b, unpubl. MECOR data) of higher $\mathrm{NO}_{3}^{-}$concentrations in water exiting the East lagoon region of Davies Reef.

Remineralization rates of ammonium in the water column over Davies Reef ranged from undetectable to $0.0112 \mu \mathrm{mol} \mathrm{NH} \mathrm{NH}_{4}^{+}-\mathrm{N}^{-1} \mathrm{~h}^{-1}$ (Table 2). There were considerable temporal and spatial differences in rates. Temporal variation in estimates of remineralization in the lagoon (ranging from undetectable to $0.0025 \mathrm{umol}$ $\mathrm{NH}_{4}^{+}-\mathrm{Nl}^{-1} \mathrm{~h}^{-1}$ ) appeared to be random and not related to tidal or diel rhythms. Variation of this magnitude may reflect a heterogeneous distribution of microbial and metazoan biomass in the water column at Davies Reef. Ammonium remineralization rates, averaged by reef region, spanned 2 orders of magnitude: highest in

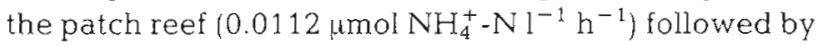

Table 2. Mean rates of pelagic ammonium regeneration at Davies Reef during August 1984. Units are umol $\mathrm{NH}_{4}^{+}-\mathrm{N}^{-1}$ $h^{-1}$

\begin{tabular}{|lccc|}
\hline Site & \multicolumn{2}{c}{ Remineralization } & $\begin{array}{c}\% \text { of total due } \\
\text { to organisms } \\
<15 \mu \mathrm{m}\end{array}$ \\
\hline $\begin{array}{l}\text { Fore-reef } \\
\text { Reef flat }\end{array}$ & 0.0013 & 0.0005 & $40 \%$ \\
$\begin{array}{l}\text { Lagoon } \\
\text { Patch reef } \\
\text { (internal) }\end{array}$ & 0.0050 & 0.0033 & $66 \%$ \\
\hline
\end{tabular}

the reef flat $\left(0.0050 \mu \mathrm{mol} \mathrm{NH}_{4}^{+}-\mathrm{N} \mathrm{l}^{-1} \mathrm{~h}^{-1}\right)$, the lagoon $\left(0.0017 \mu \mathrm{mol} \mathrm{NH} \mathrm{NH}_{4}^{+}-\mathrm{N}^{-1} \mathrm{~h}^{-1}\right)$ and the fore-reef $(0.0013$ umol $\left.\mathrm{NH}_{4}^{+}-\mathrm{Nl}^{-1} \mathrm{~h}^{-1}\right)$. Remineralization was highest in those areas where water was in most intimate contact with the reef benthos (shallow-water regions with a high proportion of benthic surface area to water volume). This may reflect a response of the pelagic community to the input of organic matter (e.g. mucus) to the water column by the reef benthos (Paul et al. 1986, Ducklow 1987).

Bacteria and heterotrophic nanoplankton, operationally defined as organisms $<15 \mu \mathrm{m}$, accounted for 40 to $88 \%$ of the $\mathrm{NH}_{4}^{+}$remineralized in $208 \mu \mathrm{m}$ filtered water at Davies Reef (Table 2). There was a trend of increasing importance of these organisms as water passed from the fore-reef, across the reef flat, into the lagoon and patch reef areas. Again, this may be a result of metabolic stimulation of the microbial community (biomass of which was spatially constant) due to the release of soluble organics such as mucus from the coral community (Paul et al, 1986, Ducklow 1987). It could also be due to removal of 15 to $208 \mu \mathrm{m}$ organisms by coral predation. There has been increasing evidence for the importance of plankton smaller than $208 \mu \mathrm{m}$ in remineralizing $\mathrm{NH}_{4}^{+}$in marine systems. Johannes (1964) was the first to demonstrate that microplanktonic excretion rates could be substantial even though their biomass was low. Likewise, Harrison (1978), Caperon et al. (1979), and Paasche \& Kristiansen (1982) demonstrated the importance of the small size classes of heterotrophic plankton in ammonium remineralization in a number of estuarine and shelf environments. Glibert (1982) and Harrison et al. (1983) documented the importance of the smallest size classes. In both the Chesapeake Bay and the Sargasso Sea, Glibert (1982) showed that organisms less than $10 \mu \mathrm{m}$ often contributed up to $100 \%$ of the $\mathrm{NH}_{4}^{+}$remineralized.

A first approximation of the relative importance of bacteria and heterotrophic nanoplankton in pelagic ammonium remineralization can be established from biomass and growth data of both groups (Table 3 ). Bacterial ammonium remineralization was estimated to be approximately 0.0007 or $0.0044 \mathrm{kmol} \mathrm{Nl}^{-1} \mathrm{~h}^{-1}$. depending on the choice of methods for measuring bacterial production (eukaryotic inhibitors and cell counts or ${ }^{3} \mathrm{H}$-thymidine incorporation rate into DNA). In our experiments, the former methods gave higher production estimates, even when we used a thymidine conversion factor of $4 \times 10^{18}$ cells mole ${ }^{-1}$ (Ducklow \& Hill 1985b).

Remineralization by heterotrophic nanoplankton was much smaller and, as for bacteria, varied depending on the method of calculation. Estimates calculated from biomass data were slightly higher than those determined from growth/respiration rates. The mean mea- 
Table 3. Estimated ammonium remineralization by bacteria and heterotrophic nanoplankton (HNAN). Bacterial biomass from Ducklow (unpubl.) and Sherr (unpubl.) direct cell counts (Hobbie et al. 1977), assuming $11 \mathrm{fg} C$ per bacterial cell (Bratbak \& Dundas 1984). Bacterial production (growth) from unpubl. data sets of Ducklow $\left({ }^{3} \mathrm{H}\right.$-thymidine incorporation into DNA: Ducklow \& Hill 1985b) and Sherr (time course cell counts with eukaryotic inhibitors: Sherr et al. 1986). HNAN production from Sherr (unpubl. protozoan grazing data: see Sherr et al. 1984). Respiration calculated from growth assuming $33 \%$ growth efficiency. Remineralization estimated from (1) respiration and Redfield stoichiometry and (2) from Sherr et al. (1983) excretion rates per unit flagellate biomass. Measured remineralization is that measured in $10 \mu \mathrm{m}$ screened water

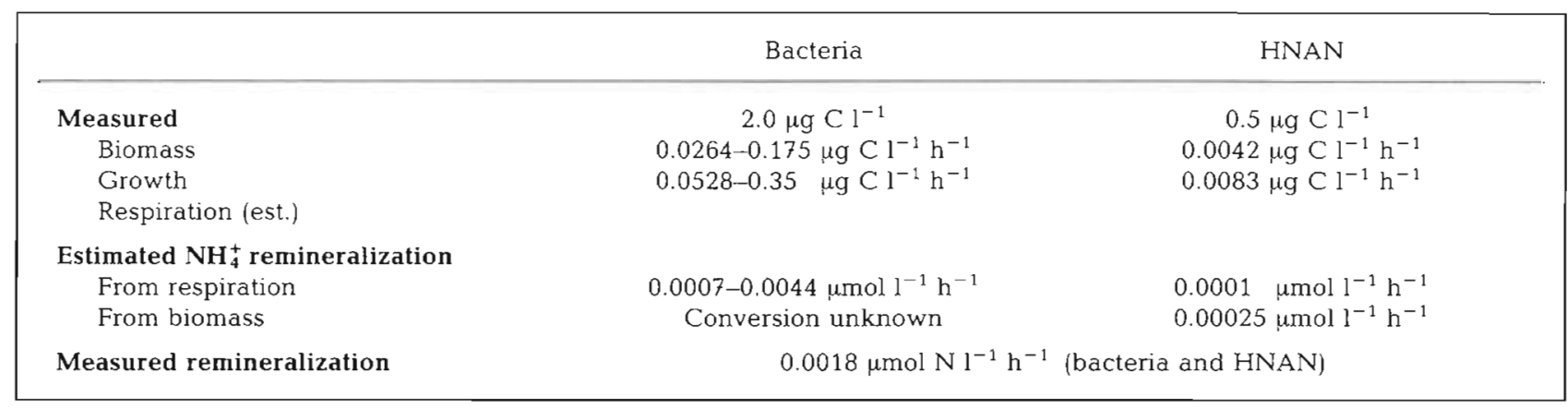

sured rate of remineralization at Davies Reef (excluding reef interstices) by plankton passing a $15 \mu \mathrm{m}$ screen

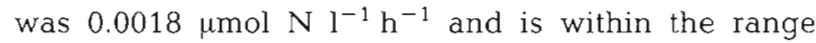
calculated for both bacteria and HNAN. These results suggest that the suspended bacteria at Davies Reef were more important as nutrient remineralizers than the heterotrophic nanoplankton at the time of our sampling. The $\mathrm{C} / \mathrm{N}$ ratio of the majority of the organic matter microbially degraded in the water column of this coral reef must have been similar to the Redfield ratio and roughly equivalent to the $\mathrm{C} / \mathrm{N}$ ratio of bacterial protoplasm, otherwise there would not have been such close agreement between measured and calculated rates of ammonium remineralization. In such a situation bacteria must release nitrogen to the environ- ment in order to maintain the proper $\mathrm{C} / \mathrm{N}$ ratios within their cells (Caron \& Goldman in press). Hopkinson et al. (unpubl.) suggested that nanoplankton assume a greater importance than bacteria in $\mathrm{N}$ remineralization only when the $\mathrm{C} / \mathrm{N}$ ratio of the organic substrates being decomposed exceeds $11: 1$.

Ammonium regeneration rates observed at Davies Reef are among the lowest reported in the literature (Table 4). They more closely resemble rates observed in the open ocean than in relatively shallow coastal and estuarine areas. This may be a consequence of the very low levels of microbial biomass and production we observed at Davies Reef (Table 2, see also Ducklow 1987). Pelagic ammonium regeneration rates measured in 2 other 'live' bottom, benthic-dominated systems,

Table 4. Rates of pelagic ammonium regeneration in several marine environments $\left(\mu \mathrm{mol} \mathrm{NH} \mathrm{N}_{4}^{+}-\mathrm{N} \mathrm{l}^{-1} \mathrm{~h}^{-1}\right)$

\begin{tabular}{|c|c|c|c|}
\hline Environment & Site & $\begin{array}{c}\text { Rate } \\
\text { (range or mean) }\end{array}$ & Source \\
\hline \multicolumn{4}{|l|}{ Estuarine } \\
\hline & Laguna de Terminos, Mexico & $0.064-0.409$ & Hopkinson et al. 1987 \\
\hline & Chesapeake Bay, USA & $0.11-1.195$ & Glibert et al. 1982 \\
\hline & Oslofjord, Norway & $0.012-0.061$ & Paasche \& Kristiansen 1982 \\
\hline & Kaneohe Bay, Hawaii & $0.010-0.162$ & Caperon et al. 1970 \\
\hline \multicolumn{4}{|l|}{ Coastal } \\
\hline & Vineyard Sound, Massachusetts, USA & $\sim 0-0.31$ & Glibert 1982 \\
\hline & Georgia Bight, USA & 0.11 & Hanson \& Robertson unpubl. \\
\hline & Bedford Basin, Nova Scotia, Canada & 0.056 & La Roche 1983 \\
\hline & CEPEX, British Columbia, Canada & $0.023-0.051$ & Harrison 1978 \\
\hline & Grays Reef, Georgia Bight, USA & $0.048-0.089$ & Falion \& Hopkinson 1986 \\
\hline & Southern California Bight, USA & $0.0006-0.0091$ & Harrison 1978 \\
\hline & Middle Atlantic Bight & $0.008-0.029$ & Harrison et al. 1983 \\
\hline & Davies Reef & $0.0013-0.0112$ & This study \\
\hline \multicolumn{4}{|l|}{ Open ocean } \\
\hline & Scotia Sea & $\sim 0-0.13$ & Glibert 1982 \\
\hline & Sargasso Sea & $0.0020-0.0646$ & Glibert et al. 1982 \\
\hline
\end{tabular}


Gray's Reef in the Georgia Bight and Kaneohe Bay in Hawaii, are approximately 20 times higher than those measured at Davies Reef. The extremely low rates of pelagic remineralization at Davies Reef reflect the low levels of pelagic primary production and the generally oligotrophic nature of the water column adjacent to and over this pristine coral reef system. Rates may be higher during summer when the water resides longer in the reef system (Kinsey 1985b, Moriarty et al. 1985, Ducklow 1987).

In shallow water systems, benthic metabolism and nutrient regeneration are generally greater than pelagic processes (Hargrave 1973). Live bottom portions of coral reefs frequently experience rates of total community production and respiration in excess of $6 \mathrm{gC} \mathrm{m}^{-2} \mathrm{~d}^{-1}$ (Kinsey 1985a); phytoplankton production is usually trivial and certainly less than $10 \%$ of total production (Lewis 1977). During the MECOR expedition benthic nutrient regeneration was measured only in lagoonal sediments. Although benthic respiration was as high as $1 \mathrm{gC} \mathrm{m}^{-2} \mathrm{~d}^{-1}$ (Hansen, unpubl. MECOR data), the ratio of primary production to respiration was nearly balanced, indicating an active, nutrient-demanding algal community. Consequently there was little net loss or flux of nutrients regenerated in the sediments to the overlying water column (about $0.62 \mu \mathrm{mol} \mathrm{N} \mathrm{m}^{-3} \mathrm{~h}^{-1}$ : Hansen pers. comm.). With respect to supplying inorganic nitrogen to the water column in lagoonal portions of Davies Reef, pelagic $N$ regeneration was almost 3 times more important than sediment nutrient regeneration (averaging $1.7 \mu \mathrm{mol} \mathrm{N} \mathrm{m}^{-3} \mathrm{~h}^{-1}$ ).

The quantitative importance of pelagic ammonium regeneration can be partially assessed by calculating the proportion of phytoplankton $N$ demand that is potentially supplied by pelagic regeneration. The estimated phytoplankton requirement of $\mathrm{N}$, calculated from the Redfield ratio and ${ }^{14} \mathrm{C}$ estimates of primary production (Furnas pers. comm.) ranged from 0.0016 to $0.0055 \mu \mathrm{mol} \mathrm{NH}_{4}^{+}-\mathrm{N}^{-1} \mathrm{~h}^{-1}$ (Table 5). In deep water

Table 5. Importance of pelagic ammonium remineralization to phytoplankton at Davies Reef (units: $\mu \mathrm{mol} \mathrm{NH}_{4}^{-}-\mathrm{N} \mathrm{l}^{-i} \mathrm{~h}$ ')

\begin{tabular}{|c|c|c|c|}
\hline Site & $\begin{array}{l}N \text { require- } \\
\text { ment }\end{array}$ & $\frac{\mathrm{N}}{\text { regenerated }}$ & $\begin{array}{l}\% \text { of } \\
\text { requirement }\end{array}$ \\
\hline Fore-reef & 0.0033 & 0.0013 & 39 \\
\hline Reef flat & 0.0016 & 0.0050 & 313 \\
\hline Lagoon & 0.0055 & 0.0017 & 31 \\
\hline \multicolumn{4}{|c|}{$\begin{array}{l}\text { - Requirement calculated from areal daily carbon produc- } \\
\text { tion estimates for fore-reef and lagoon sites and volumet- } \\
\text { ric rates for the reef flat, a } \mathrm{C}: \mathrm{N} \text { uptake ratio of } 106: 16 \text {, a } \\
24 \text { h interval for } \mathrm{N} \text { uptake, and depths of } 60 \text {, and } 20 \mathrm{~m} \text { for } \\
\text { fore-reef and lagoon sites, respectively }\end{array}$} \\
\hline
\end{tabular}

sites outside and in Davies Reef, pelagic ammonium regeneration supplied only about a third of phytoplankton requirements. Given the uncertainties of sampling, analysis, Redfield ratio deviations and conversion factors, it is hard to determine whether this deficit is significant or real. It suggests that perhaps macrozooplankton are also important agents of $\mathrm{N}$ recycling in deep waters of Davies Reef. In the shallow reef flat area, however, considerably more $\mathrm{N}$ was regenerated by organisms $<208 \mu \mathrm{m}$ than was needed by the phytoplankton drifting over the flat. Although the water residence time over the reef flat precluded the identification of an upstream-downstream $\mathrm{NH}_{4}^{+}$concentration gradient on the reef flat, it appears as if some inorganic nitrogen was being made available for export to the adjacent lagoonal system.

On the basis of pelagic ammonium remineralization and standing stock concentrations, turnover times of ammonium in the water column at Davies Reef ranged from 21 to $154 \mathrm{~h}$. Long ammonium turnover times relative to estimated water residence times (Kinsey pers. comm., Pickard 1986, and pers. comm.) suggest a greater importance of physical rather than biological processes in the water column of Davies Reef during the winter when we sampled.

A number of factors, including low rates of pelagic ammonium remineralization, low phytoplankton productivity, short water residence times, a lack of nutrient concentration gradients, and high rates of benthic and total system metabolism, demonstrate the almost trivial importance of heterotrophic microbial processes occurring in the water column of Davies Reef during the period of observation (Ducklow 1987). The general description of a coral reef system (Odum 1971) is of high gross productivity, low net ecosystem production, highly conservative nutrient behavior and benthic community dominance. Our work on pelagic ammonium recycling fully supports this description. We found no evidence of net nutrient uptake or release from Davies Reef. We did find evidence, however, that pelagic processes were stimulated by contact with the benthos and that there might be intrasystem transfers of ammonium within Davies Reef.

Acknowledgements. Special thanks are extended to Clive Wilkinson, Don Kinsey, Dave White and David Moriarty for conceiving and organizing the MECOR project, for invitung us to participate in MECOR, for assisting with logistical problems in Australia, for opening their laboratories to us at the Australian Institute of Marine Science and for their overall hospitality during our visit. We also thank the crew of the M/V Reef Seeker for all the help they gave us at sea. Figures were prepared by Cindy Holcombe at the Marine Institute. This work was jointly sponsored by NOAA, Office of Sea Grant, Department of Commerce, under Grant No. NA80AA-D00091, the National Science Foundation (INT-8312117) USAustralia Cooperative Science Program), and the Australian Institute of Marine Science 


\section{LITERATURE CITED}

Andrews, J., Muller, H. (1983). Space-time variability of nutrients in a lagoonal patch reef. Limnol. Oceanogr. 28: $215-227$

Blackburn, T. H. (1979). Method for measuring rates of $\mathrm{NH}_{4}^{+}$ turnover in anoxic marine sediments using a ${ }^{15} \mathrm{~N}-\mathrm{NH}_{4}^{+}$ dilution technique. Appl. environ. Microbiol. 37: 760-765

Bratbak, G., Dundas, I. (1984). Bacterial dry matter content and biomass estimations. Appl. environ. Microbiol. 48: $755-757$

Caperon, J., Schell, D., Hirota, J., Laws, E. (1979). Ammonium excretion rates in Kaneohe Bay, Hawaii, measured by a ${ }^{15} \mathrm{~N}$ isotope dilution technique. Mar. Biol. 54: 33-40

Caron, D. A., Goldman, J. C. (in press). Nutrient regeneration. In: Capriulo, G. M. (ed.) The ecology of marine protozoa. Oxford Univ, Press, New York

Ducklow, H. W. (1987). The biomass, production and fate of bacteria in coral reefs. In: Dubinsky, Z. (ed.) Coral reefs. Springer-Verlag, Heidelberg (in press)

Ducklow, H. W., Hill, S. (1985a). The growth of heterotrophic bacteria in the surface waters of warm core rings. Limnol. Oceanogr. 30: 239-259

Ducklow, H. W., Hill, S. (1985b). Tritiated thymidine incorporation and the growth of heterotrophic bacteria in warm core rings. Limnol. Oceanogr. 30: 260-272

Dudek, N., Brzezinski, M., Wheeler, P. (1986). Recovery of ammonium nitrogen by solvent extraction for the determination of relative ${ }^{15} \mathrm{~N}$ abundance in regeneration experiments. Mar. Chem. 18: 59-69

Dugdale, R. C., Goering, J. (1967). Uptake of new and regenerated forms of nitrogen in primary productivity. Limnol. Oceanogr. 12: 196-206

Fallon, R. D., Hopkinson, C. S. (1986). Community metabolism and nutrient fluxes at Gray's Reef National Marine Sanctuary. NOAA Technical Report Series OCRM/SPD

Glibert, P. M. (1982). Regional studies of daily, seasonal and size fraction variability in ammonium remineralization. Mar. Biol. 70: 209-221

Glibert, P. M., Lipschultz, F, McCarthy, J. J., Altabet, M. (1982). Isotope dilution models of uptake and remineralization of ammonium by marine plankton. Limnol. Oceanogr. 27: 639-650

Hargrave, B. T. (1973). Coupling carbon flow through some pelagic and benthic communities. J. Fish. Res. Bd Can. 30: $1317-1326$

Harrison, W. G. (1978). Experimental measurements of nitrogen remineralization in coastal waters. Limnol. Oceanogr. 23: 684-694

Harrison, W. G. (1980). Nutrient regeneration and primary production in the sea. In: Falkowski, P. (ed.) Primary productivity in the sea. Plenum Press, New York, p. 433-460

Harrison, W. G., Douglas, D., Falkowski, P., Rowe, G., Vidal, J. (1983). Summer nutrient dynamics of the middle Atlantic Bight: nitrogen uptake and regeneration. J. Plankton Res. 5: 539-556

Hobbie, J., Daley, R., Jasper, S. (1977). Use of nucleopore filters for counting bacteria by epifluorescence microscopy. Appl. environ. Microbiol. 33: 1225-1228

Hopkinson, C. S., Kipp, S., Stevenson, J. C. (1987). Nitrogen pools and turnover times in a tropical seagrass system. In: Yanez-Arancibia, A., Day, J. (ed.) Ecology of coastal sys- tems in the southern Gulf of Mexico. UNAM-CONACYT Publication, Mexico City (in press)

Johannes, R. E. (1964). Phosphorous excretion as relative to body size in marine animals: microzooplankton and nutrient regeneratoin. Science 146: 923-924

Johannes, R. E. (1967). Ecology of organic aggregates in the vicinity of a coral reef. Limnol. Oceanogr 13: 189-195

Johannes, R. E. and 21 others (1972). The metabolism of some coral reef communities: a team study of nutrient and energy flux at Eniwetok. Bioscience 22: 541-543

Kinsey, D. W. (1985a). Metabolism, calcification and carbon production. In: Proceedings 5th Coral Reef Symposium. Ephe Publisher, Moorea, French Polynesia, p. 503-526

Kinsey, D. W. (1985b). The functional role of back-reef and lagoonal systems in the central Great Barrier Reef. In: Proceedings 5th International Coral Reef Congress, Tahiti, 1985, Vol, 6. Ephe Publisher, Moorea, French Polynesia, p. $223-228$

La Roche, J. (1983). Ammonium regeneration: its contribution to phytoplankton nitrogen requirements in a eutrophic environment. Mar. Biol. 75: 231-240

Laws, E. (1984). Isotope dilution models and the mystery of the vanishing ${ }^{15} \mathrm{~N}$. Limnol. Oceanogr. 29: 379-385

Lewis, J. B. (1977). Processes of organic production on coral reefs. Biol. Rev. 52: 305-347

McCarthy, J. J., Taylor, W., Taft, J. (1977). Nitrogenous nitrogen of the phytoplankton in the Chesapeake Bay. I. Nutrient availability and phytoplankton preferences. Limnol. Oceanogr. 22: 996-1010

Moriarty, D. J. W., Pollard, P. C., Hunt, W. G. (1985). Temporal and spatial variation in bacterial production in the water column over a coral reef. Mar Biol. 85: 285-292

Odum, E. P. (1971). Fundamentals of ecology. W. B. Saunders, Philadelphia

Paasche, E., Kristiansen, S. (1982). Ammonium regeneration by microzooplankton in the Oslofjord. Mar. Biol 69: 55-63

Paul, J. H., DeFlaun, M. F., Jeffrey, H. (1986). Elevated levels of microbial activity in the coral surface microlayer. Mar. Ecol. Prog. Ser. 33: 29-40

Pickard, G. L. (1986). Effects of wind and tide on upper-layer currents at Davies Reef, Great Barrier Reef, during MECOR. Aust. J. mar Freshwat. Res. 37: 545-565

Ryther, J. H., Dunstan, W. (1971). Nitrogen, phosphorus and eutrophication in the coastal marine environment. Science 171: 1008-1012

Sherr, B. F., Sherr, E. B., Berman, T. (1983). Grazing, growth and ammonium excretion rates of a heterotrophic microflagellate fed with four species of bacteria. Appl. environ. Microbiol. 45: 1196-1201

Sherr, B. F., Sherr, E. B., Newell, S. Y. (1984). Abundance and productivity of heterotrophic nanoplankton in Georgia coastal waters. J. Plankton Res. 6: 195-202

Sherr, B. E., Sherr, E. B., Andrews, T. L., Fallon, R. D., Newell, S. Y. (1986). Trophic interactions between heterotrophic Protozoa and bacterioplankton in estuarine water analyzed with selective metabolic inhibitors. Mar. Ecol. Prog. Ser. 32: 169-179

Strickland, J. D. H., Parsons, T. R. (1972). A practical handbook of seawater analysis. Bull. Fish. Res. Bd Can. 167: 1-311

Webb, K. L., DuPaul, W., Wiebe, W., Sottile, W., Johannes, R. (1975). Enewetak (Eniwetak) Atoll: aspects of the nitrogen cycle on a coral reef. Limnol. Oceanogr. 20: 198-210 